\title{
Blended learning design for teaching innovation: university teachers' perceptions ${ }^{1}$
}

\author{
Katia Sannicandro ${ }^{\mathrm{a}}$, Annamaria De Santis ${ }^{\mathrm{b}}$, Claudia Bellinic ${ }^{\mathrm{c}}$, Tommaso Minerva ${ }^{\mathrm{d}}$ \\ ${ }^{a}$ University of Modena and Reggio Emilia, katia.sannicandro@unimore.it; \\ https:/lorcid.org/0000-0001-6364-1786; \\ ${ }^{b}$ University of Modena and Reggio Emilia, annamaria.desantis@unimore.it; \\ https://orcid.org/0000-0001-7680-2956 \\ cUniversity of Modena and Reggio Emilia, claudia.bellini@unimore.it; \\ https://orcid.org/0000-0001-5220-0694 \\ ${ }^{d}$ University of Modena and Reggio Emilia, tommaso.minerva@unimore.it; \\ https://orcid.org/0000-0001-8612-698X
}

\begin{abstract}
In the Italian university context, almost all universities offer blended degree courses, digital environments and e-learning systems. In many cases, dedicated centres also provide technical support and, less frequently, teaching and methodological support. The development of digital learning environments often does not correspond to the spread of an effective culture of educational innovation in university courses.

The research examined the experiences of instructional design among 44 university teachers of blended degree courses at the University of Modena and Reggio Emilia. The analysis focused on teachers' level of satisfaction and the processes of teaching innovation linked to the blended methodology, investigating also the possible criticalities and strengths related to the process of (re)design and innovation. The activities of training and design for teachers contributed to the dissemination of good teaching practices and professional development.

In line with what emerged from the research on blended learning, it seems necessary to build a framework for the adoption and implementation of 'blended learning' strategies at the institutional level, starting from the construction of a concrete agenda setting shared between the actors of the innovation process.
\end{abstract}

Keywords: Blended Learning; Instructional Design; Digital Education; Distance Education; Professional Development.

\section{Introduction}

A report published by the Open University in collaboration with the Centre for the Science of Learning and Technology (SLATE) at the University of Bergen (Ferguson et al., 2019) highlights the increasing diffusion of new educational theories and practices. These 'innovative pedagogies', however, do not proceed with a careful interpretation of the concept of learning, wrongly understood as something 'to be consumed': 'learning is not presented as an enjoyable or stimulating activity'. Taking up the words of Stephen Downes, the authors of the report state that 'the core of learning is found not in what is defined in the curriculum, but in how teachers help students discover new possibilities from familiar things, and then from new things' (p. 6). This conception shifts the attention to the teachers' and the students' role and their link with instructional design processes.

\footnotetext{
${ }^{1}$ The contribution represents the result of a joint work of the authors who collaborated in all the phases of the research work. Katia Sannicandro wrote the sections Introduction, Methods, and Results and Discussion; Annamaria De Santis wrote the section Blended Degree Courses at Unimore; Claudia Bellini wrote the section Conclusions and Future Research Directions and Tommaso Minerva provided the general setting of the paper.
} 
In the Italian context, almost all universities offer blended courses, digital environments and e-learning systems. In many cases, university centres are organised to provide technical support and, less frequently, teaching and methodological support.

As it also emerged from the international context (in the periods before the COVID-19 health emergency), there is a clear need to activate centres that can combine the functions and activities of instructional design centres with the development of programmes designed to innovate teaching and learning processes. An example of this can be found at the Center for Innovative Teaching and Learning (CITL) (Northern Illinois University), which offers a specific service of course design partnerships (Sannicandro et al., in press). This element is linked not only to instructional design processes, but also (and especially) to teachers' professional development and faculty development processes to foster, enhance and recognise teachers' competencies (Lotti \& Lampugnani, 2020) and to provide - as described by Perla and Vinci (2020) support to university teaching that can act on curricular and methodological innovation processes.

The development of digital learning environments often does not correspond to the spread of an effective culture of educational innovation in university courses, despite the good practices and numerous researches that were carried out in recent years (Ferrari \& Rivoltella, 2006; Federighi, Ranieri \& Bandini, 2019; Triacca, Bodega \& Rivoltella, 2019). The instructional design process, necessary for the realisation of blended degree courses, involves different, but simultaneously interconnected actors and processes. No aspect can be excluded for the successful outcome of the development and design process.

If we focus on teachers' perspectives, it becomes necessary to investigate the dynamics connected to design and all the aspects linked to a single course (e.g., assessment process, management of collaborative activities or content to redesign). These elements are connected to the learning processes, to the management of online interaction and to the assessment methods in non-traditional environments (Gikandi, Morrow \& Davis, 2011). Unimore guidelines on blended course design underline that this delivery mode improves the effectiveness of interaction between teachers and students and enhances the opportunities of working students, students with disabilities or special educational needs, and other special categories for participating in the class and 'living' (also online) university contexts (Sannicandro et al., 2018).

In line with what has emerged from the research on blended learning (Graham et al., 2006, 2013; Spring et al., 2017; Borup et al., 2020), the importance of building a framework for the adoption and implementation of 'blended learning' strategies at an institutional level seems evident, starting from the co-construction of concrete agenda setting shared between the actors of the innovation process (Rogers, 2003). In this regard, Graham and colleagues (Graham, Woodfield \& Harrison, 2013) repropose the model of Rogers (2003) for the phases linked to innovation processes and applicable to the introduction of blended modes (see Fig.1).



Fig. 1. Everett Rogers' proposal - Five Stages in the Innovation Process in an Organization (2003, p. 392).

The model effectively fosters the integration of innovation processes in the 'conventional' activities in the organisational contexts and, therefore, also in the complex university scenario. The recent unfortunate COVID-19 emergency has highlighted precisely the need to have a strong methodological and planning framework at the system level (and not only for individual teachers) to cope with the rethinking of teaching methods, even for traditional training courses. 


\section{Blended Degree Courses at Unimore}

Actually, at the University of Modena and Reggio Emilia, three Bachelor's degree courses and one Master's degree course were delivered in a blended mode (see Table 1).

Table 1. Blended degree courses at Unimore

\begin{tabular}{|c|c|c|c|}
\hline Degree course & Year of activation & $\begin{array}{l}\text { No. of enrolled students - first } \\
\text { year of activation }\end{array}$ & $\begin{array}{l}\text { No. enrolled students - a.y. } \\
2020-2021\end{array}$ \\
\hline $\begin{array}{l}\text { Psychological Sciences and Techniques (in } \\
\text { collaboration with the University of Parma) }\end{array}$ & а.у. $2015-2016$ & $\begin{array}{l}269 \\
\text { (limited access) }\end{array}$ & $\begin{array}{l}314 \\
\text { (limited access) }\end{array}$ \\
\hline Education & a.y. 2016-2017 & 445 & $\begin{array}{l}\text { The course is now delivered in a } \\
\text { traditional way }\end{array}$ \\
\hline $\begin{array}{l}\text { Legal Services in Business and Public } \\
\text { Administration }\end{array}$ & a.y. 2018-2019 & 136 & 228 \\
\hline Labour relations & a.y. 2016-2017 & 57 & 110 \\
\hline Digital Education & a.y. $2019-2020$ & 129 & 183 \\
\hline
\end{tabular}

The courses in 'Psychological Science and Techniques' and 'Digital Education' have been set up in the blended mode since the first activation; the other courses changed their delivering mode at the dates given in Table 1, shifting to blended from the traditional way. All the courses provide online training activities for a proportion of between $30 \%$ and $70 \%$, according to Ministerial Decree no. 635 of 8 August 2016 and Ministerial Decree no. 6/2019 about quality evaluation and accreditation of courses.

A Moodle-based portal hosts all the courses (Fig. 2). A common area called 'virtual campus' is accessible to all students and allows the learners to share online spaces and communicate among different courses, to create areas for discussion on topics related to their personal and professional growth and to contact the technical helpdesk and online secretariat (Sannicandro et al., 2018) through forum.

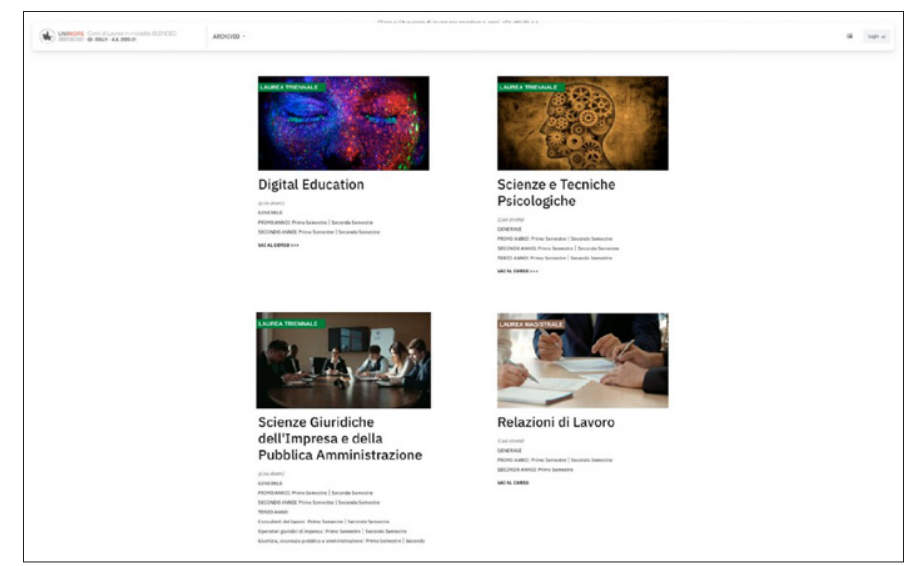

Fig. 2. Portale Blended Unimore (https://dolly.blended.unimore.it/2020/)

The portal is the crucial node from which all learning activities start and return and where the online learning environment plays a fundamental role. According to Varisco's (2002) description, a learning environment must weave together 'a set of relationships that bind together, in a more or less dynamic way, the various actors operating in the environment [. It is, therefore] a climate that arises not only from the type of relationships established between the actors but also from the way tasks and activities are carried out' (p. 156, our translation).

The educational dimension appears to be closely linked to the training setting. Garavaglia and Petti (2019) present a reflection related to the redesign of the setting in the university context, providing concrete examples related to the pervasiveness of devices, the growing role of the inverted classroom and the importance of feedback and experiential learning. These are dimensions related to the 'rethinking' of training models based on student-centred or teacher-centred approaches (Garavaglia \& Petti, 2019) that we also find in online training contexts.

\section{Methods}

The research is part of a broader series of study initiated by the research group belonging to the Edunova Inter-University Centre at the University of Modena and Reggio Emilia concerning the processes of design and redesign of blended courses (Sannicandro et al., 2018; Cecconi, Sannicandro \& Bellini, 2019; Bellini, et al., 2020) in the field of instructional design. 


\section{Blended learning design for teaching innovation: university teachers'perceptions}

Sannicandro, K., De Santis, A., Bellini, C., Minerva, T.

The research actions carried out by the working group concern:

1.the design and development of blended degree courses following the previous experiences in the design of totally online courses;

2. the drafting of guidelines for the design of blended courses;

3. teachers' training on teaching innovation processes, not only related to the blended model;

4. the development of a system of support by experts (e.g., instructional designers) for the design of each degree course;

5. the monitoring of activities on training courses for teachers and students and

6. the development of a system for the professional recognition of teachers' teaching and methodological skills, also concerning faculty development processes.

The research and monitoring activities related to blended degree courses and related educational innovation processes (point 6) have been initiated since November 2018.

The last actions of monitoring and developing a system for professional recognition have been revised ('paused' for the monitoring) in light of the COVID-19 emergency, which has heavily influenced the course design and development and affects the processes by which students use the teaching content.

For these reasons, the contribution focuses on the first phases of the monitoring actions begun with the construction and administration of a questionnaire addressed to teachers. The research focused on collecting data related to the level of satisfaction and the processes of didactic innovation linked to the blended methodology, also investigating possible criticalities and strengths related to the process of redesign and didactic innovation before the health emergency.

The questionnaire, consisting of 33 questions, 9 of which were open-ended, was administered anonymously online to the teachers of the blended degree courses previously mentioned. It included three areas of investigation related to:

1.the relationship between teaching and blended mode;

2. the use of the portal and teaching resources

3. the relationship between blended mode and students.

The questionnaire was shared with the instructors through SurveyMonkey, an online survey software.

The teachers involved in the survey had carried out their teaching in a previous semester; therefore, they had completed the design actions. Forty-four out of 69 teachers replied to the survey (64\%).

A small group of teachers read and tested the questionnaire before it was administered.

The research questions that guided the present work are as follows:

1. Can blended teaching influence and modify 'the way of teaching' of teachers even in 'traditional' teaching contexts?

2. How can the processes of redesign and training for teachers in the blended learning model foster and contribute to constructing a system of educational innovation and professional development/recognition in the university context?

\section{Results and Discussion}

Results showed that $48.8 \%$ of the teachers taught Degree Course in Psychological Sciences and Techniques, 27.9\% in Educational Sciences, 20.9\% in Labour Relations and the remaining 2.3\% in Legal Sciences of Enterprise and Public Administration (Fig. 3). Teachers in Digital Education were not involved because the courses were still in the first phase of activation.

Also, $2.9 \%$ of the respondents belonged to the historical/philosophical, technical/linguistic and scientific fields, $11.8 \%$ to the pedagogical/educational and socio-economic fields, $17.7 \%$ to the law field and $50 \%$ to the psychological field; $31.7 \%$ of the teachers assessed their digital competences as sufficient, while $58.5 \%$ stated that they had good digital competences. The role and development of teachers' competences (digital and not digital) is crucial for the success of educational innovation projects.

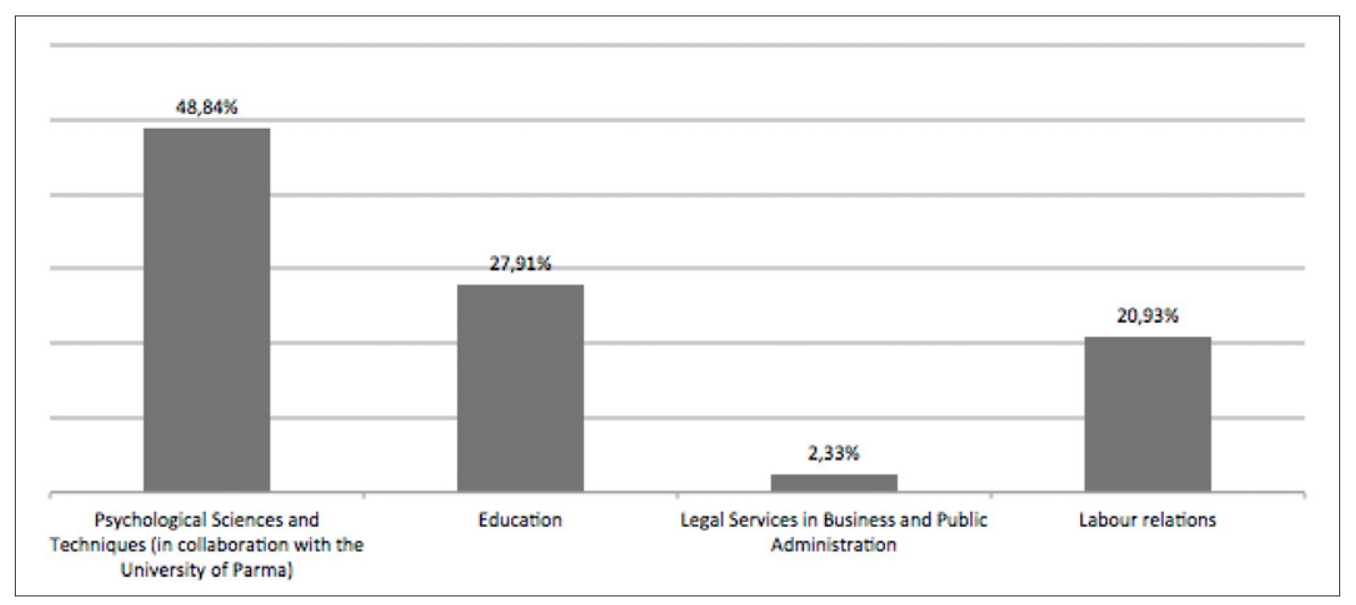

Fig. 3. Distribution of teachers by degree courses. 


\section{Blended learning design for teaching innovation: university teachers'perceptions}

Sannicandro, K., De Santis, A., Bellini, C., Minerva, T.

In the first area of the survey - relationship between teaching and blended mode - a good level of satisfaction emerged with the blended mode adopted in the course of study and in relation to their discipline. Specifically, more than $63 \%$ said they were 'very' satisfied and 19\% said 'very much'. In free comments, some positive aspects emerged: flexibility and modularity offered by the design of the blended course and better students' performance according to teachers' perception (also, thanks to the support of the video lectures produced). As mentioned previously, some of the courses in the contribution are not 'born' in blended mode, but were previously delivered in traditional mode. This element allowed a comparison between the different teaching 'experiences' lived by the teachers, in particular, on:

1.the quality of their teaching,

2. learning processes,

3. dynamics of communication and participation in the classroom and

4. assessment methods.

It emerges, moreover, the advantage linked to the fall of the rules related to the registered presence of students in the class and facilitating for learners with special educational needs and working students. For $74.2 \%$ of teachers, the blended mode succeeds in being inclusive.

Some criticalities regard the presence of non-online activities in the classroom and the participation in some specific moments (e.g., virtual classrooms dedicated to exercises and so on).

Still referring to the level of satisfaction, $88.2 \%$ (50.0\% probably yes; $38.2 \%$ certainly yes) of the teachers said they would recommend the blended mode to a colleague: $79.4 \%$ thought the blended mode is effective with respect to their teaching. Strengths are linked to the possibility to 'deepen subjects that, sometimes, risk being neglected in traditional courses for reasons of time/space and greater opportunity to interact with the students' group'.

The good practices tested and acquired in the training course are also replicated in different teaching contexts, therefore not limited to the blended experience, contributing to the dissemination of teaching innovation dynamics in the university.

These practices closely concern the process of instructional design, starting from the basic choices related to the construction of an online course, such as rethinking the structure of one's teaching, choosing the most suitable mode of use (synchronous, asynchronous activities, virtual classrooms), integrating diversified teaching methods (team-based learning, flipped approaches, etc.). To this end, training meetings are held with individual teachers to design their course; these processes require the presence of specific professional figures such as instructional designers, discipline tutors and so on. They allowed us to develop guidelines for designing and delivering online/blended courses, with particular attention to interactive online activities (Sannicandro et al., 2018).

The redesign process required a deep reflection on teaching practices and an increased focus on learning objectives and student outgoing skills. In the Digital Education degree course, this has led to the creation of working groups made up of teachers on curricula envisaged by the courses: instructional designer in digital contexts, psychosocial educator in digital contexts and digital educator in social/health contexts.

In order to investigate the levels of participation and engagement in training and didactic innovation actions, we asked teachers if they have carried out and/or participated in didactic innovation projects or training initiatives in the last 3 years. In the first case $72.7 \%$ answered negatively to the question; it was the same in the second case with a similar percentage (76.5\%). The training and project actions on blended model have, therefore, been a valuable opportunity to fill these two aspects, both related to the research questions from which we started. The activities that constituted this research pathway contributed (in the different phases described) - as we will see in the continuation of the analysis of the data collected - to the dissemination of good practices for professional development also.

Exactly $83.9 \%$ stated that they are interested in continuing their training in the future. Among the themes/topics of interest for the future, there was also a specific reference to the construction of a teaching community.

With regard to the use of tools and resources integrated in the online learning environment, it emerges that there is still little use of some resources, in particular, those useful for designing interactive teaching activities, to the advantage of 'classic' solutions: forums for news, $73.5 \%$ (less forums for discussion and comparison, 58.8\%); file sharing (pdf, slides, etc.), $73.5 \%$; tools for streaming, $47 \%$. In more detail:

- Forum for news $81.4 \%$

- Discussion forums on course topics $46.5 \%$

- Glossary $4.7 \%$

- Wiki $0.0 \%$

- Feedback 2.3\%

- Choice $4.7 \%$

- Database 0\%

- Agenda 18.6\%

- Resources/tools for self-evaluation $18.6 \%$

- Assessment resources/tools for final assessment 18.6\%

- Resources/file-sharing tools (pdf, links, etc.) $72.1 \%$

- Resources/tools for the management of virtual classrooms $76.7 \%$

- Others $2.3 \%$ 
Despite this critical aspect, the same tools and resources are also used in other non-blended teaching/courses (56\%). The research team was aware of the criticality and difficulties faced by teachers in integrating certain tools and resources into their teaching activities, also because of their possible integration into differentiated teaching methodologies and strategies. This aspect is confirmed by the question concerning the activities carried out during the virtual classrooms (an online interactive meeting per week lasting about 1 hour for the whole duration of each course), often dedicated to in-depth analysis, review, etc. and, to a lesser extent, to activities of comparison among peers. Owston and Dennis point out in their study (2011), 'the overwhelming body of research on blended learning indicates that the inclusion of on-site, face-to-face, sessions where active student participation and interaction with course content are encouraged tend to be more successful and supported by students as they help to establish immediate physical contact with other students in the class' (p. 23).

Further confirmation emerges from the question regarding the methods considered most suitable for teaching of their discipline on a scale from 'not at all' to 'very much'. Seventy per cent of the teachers indicated 'very much' for the frontal lesson in the class, $46.9 \%$ indicated 'very much' for the classroom exercises, $31.3 \%$ for experts' interventions, $28.1 \%$ (very much) and 34.4\% (much) for small group work in presence and 31.3\% (much) for the same option online. In the last year (in the midst of the pandemic), we received an increasing demand for the methods and tools to implement and integrate this mode in numerous courses, not only blended and not only at university.

To the question 'Has blended mode changed your way of teaching?', 72.7\% answered 'yes', providing (in the comments section) important food for thought for research. For example, the change is linked to the possibility of 'achieving new objectives and improving teaching methods' or 'the possibility of giving practical examples and specifying aspects that could hardly be explained at length in traditional lessons'. Still, in some cases, the importance of having feedback from the students emerges, hence a renewed attention to the quality of one's teaching related to the learning processes. However, there is still a lack of attention paid to active teaching methodologies and assessment processes in digital contexts.

In accordance with Boelens and colleagues (2017, p. 2), the design of learning environments brings with it four key challenges: (1) incorporating flexibility, (2) stimulating interaction, (3) facilitating students' learning processes and (4) fostering an effective learning climate. According to the authors, this implies 'a redefinition of education, where technology is used to design teaching activities that were previously difficult to organise, rather than a replacement, where technology is used to carry out existing activities, without any functional change in teaching and learning'. This criticality is also linked, for example, to the assessment process. About $66.7 \%$ of respondents do not use digital tools and resources for assessment/ self-evaluation (rubrics, mid-term tests, etc.) integrated in the digital learning environment. In addition, 74.2\% answered 'no' to the question 'Have you reconsidered the way you assess your teaching because of the online delivery of the course?' and about 58\% stated that they have done (or will do) the assessment tests linked to the final exam without digital tools.

In order to document the effects of the blended model on the didactic innovation processes of our university linked to the didactic processes of the (re)designed courses related to the research questions that orient and guide our work, the teachers were asked 'How much the carrying out of your teaching in blended mode has influenced your conceptions on...' and the aspects are discussed in Table 2 and Fig. 4.

Table 2. How much has your blended teaching influenced your views on $1 / 4$ ?

\begin{tabular}{lllll}
\hline & Not At all (\%) & Little (\%) & Very much (\%) & A lot (\%) \\
\hline Didactics & 8.3 & 22.2 & $\mathbf{6 1 . 1}$ & 8.3 \\
Assessment & 18.9 & $\mathbf{4 3 . 2}$ & 35.1 & 2.7 \\
Instructional design & 8.1 & 16.2 & $\mathbf{4 8 . 7}$ & $\mathbf{2 7 . 0}$ \\
Relation/interaction with students & 8.3 & 19.4 & $\mathbf{5 0 . 0}$ & 22.2 \\
Educational technologies & 5.4 & 32.4 & $\mathbf{4 6 . 0}$ & 16.2 \\
Online learning environments & 2.7 & 35.4 & $\mathbf{4 8 . 7}$ & 13.5 \\
Face-to-face teaching setting & 11.1 & $\mathbf{4 7 . 2}$ & 30.6 & 11.1 \\
Online educational setting & 5.6 & 30.6 & $\mathbf{4 4 . 4}$ & 19.4 \\
\hline
\end{tabular}

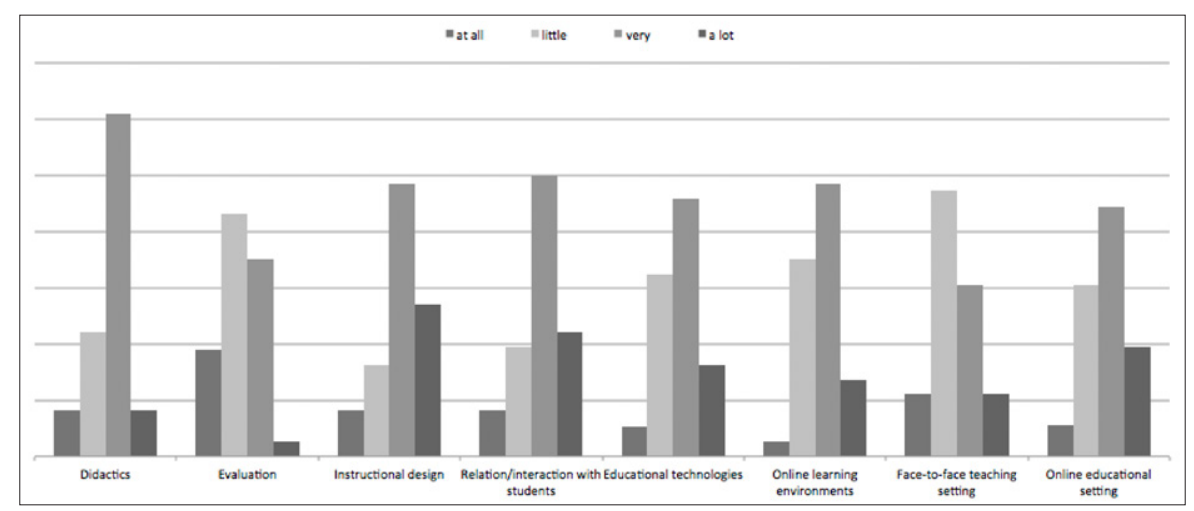

Fig. 4. Q27: How much has your blended teaching influenced your views on $1 / 4$ ? 
As highlighted, assessment represents the critical figure of the redesign process, while there are clear positive effects on teaching (61.1\% indicated 'very') and instructional design processes (48.7\% 'very' and 27.0\% 'a lot'). We also find correspondence regarding the relationship and interaction processes with students (50.0\% 'very').

The teachers were asked about their degree of agreement/disagreement on the aspects presented in Table 3 and Fig.5.

Table 3. Please indicate how much you agree with the following statements

\begin{tabular}{|c|c|c|c|c|}
\hline & $\begin{array}{l}\text { Completely } \\
\text { disagree }(\%)\end{array}$ & $\begin{array}{l}\text { More disagree } \\
\text { than agree }(\%)\end{array}$ & $\begin{array}{l}\text { More agree than } \\
\text { disagree }(\%)\end{array}$ & $\begin{array}{l}\text { Totally agree } \\
(\%)\end{array}$ \\
\hline $\begin{array}{l}\text { Use of digital tools makes lessons quicker and more } \\
\text { interactive }\end{array}$ & 13.5 & 32.4 & 37.8 & 16.2 \\
\hline Students' participation does not improve in blended mode & 10.8 & 40.5 & 32.4 & 16.2 \\
\hline Blended mode has a positive effect on students' motivation & 16.2 & 29.7 & 43.2 & 10.8 \\
\hline $\begin{array}{l}\text { Preparation of teaching activities in this mode requires } \\
\text { more time and effort }\end{array}$ & 5.4 & 13.5 & 46.0 & 35.1 \\
\hline Digital resources enhance teacher-student interactions & 13.5 & 40.5 & 29.7 & 16.2 \\
\hline Digital resources enhance student interactions & 22.9 & 45.7 & 25.7 & 5.7 \\
\hline Blended mode facilitates active student participation & 27.0 & 27.0 & 35.1 & 10.8 \\
\hline $\begin{array}{l}\text { It is not possible in all cases to make the contents of my } \\
\text { discipline available in the blended mode }\end{array}$ & 24.3 & 27.0 & 32.4 & 16.2 \\
\hline Learning of subject content is enhanced in blended mode & 5.7 & 40.0 & 42.9 & 11.4 \\
\hline Distance between teacher and student increases & 19.4 & 38.9 & 27.8 & 13.9 \\
\hline $\begin{array}{l}\text { Blended learning should involve individual discipline and } \\
\text { not courses of study }\end{array}$ & 37.8 & 29.7 & 24.3 & 8.1 \\
\hline
\end{tabular}

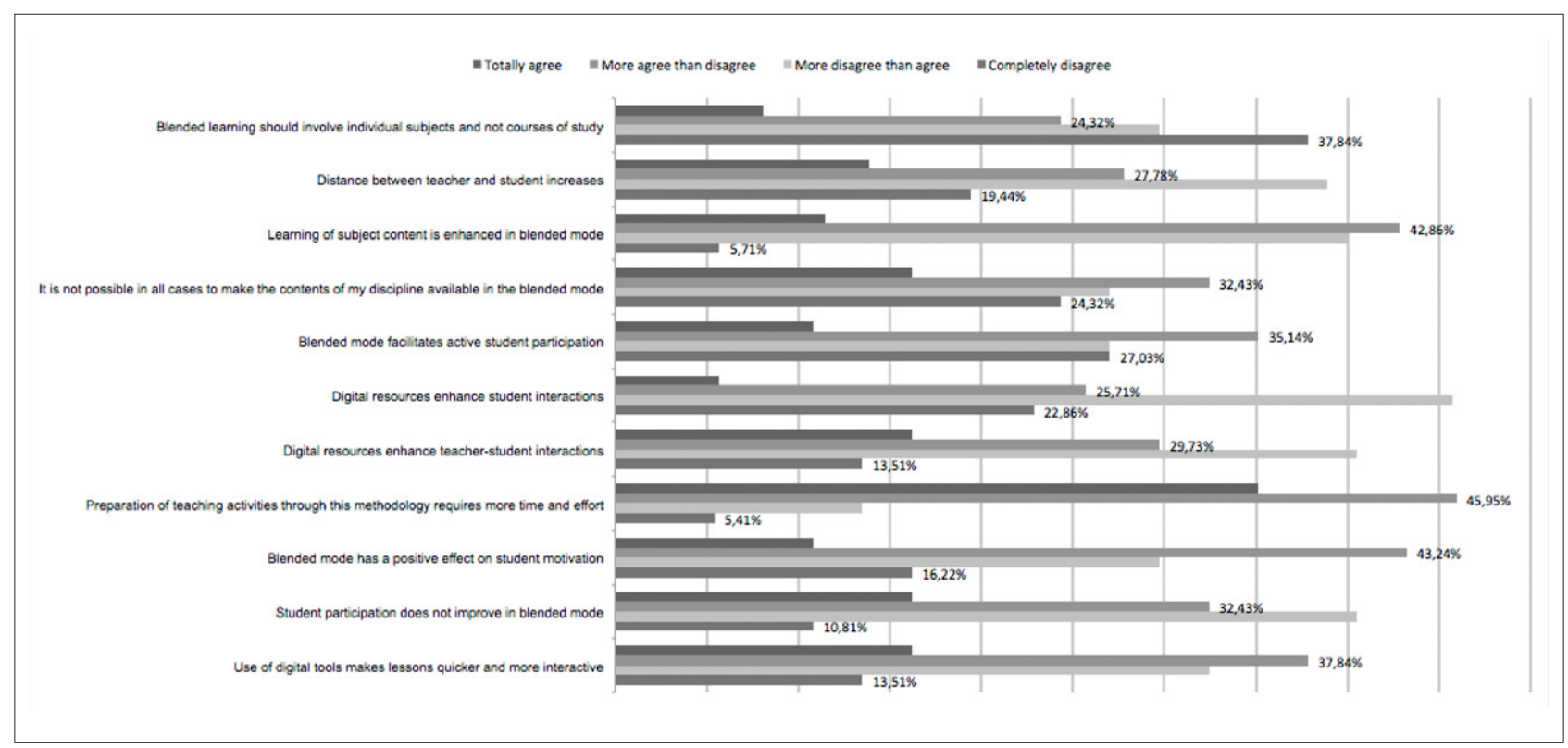

Fig. 5. Please indicate how much you agree with the following statements.

In particular, being aware of the perceptions and doubts of some teachers (criticalities that emerged during the course redesign and from the interviews with the group of teachers) related to participation (in many cases understood as physical presence in the classroom during the lessons in presence), we focused our attention on the contrast experienced by teachers between physical and digital settings. In particular, the criticality related to the management and activities of the virtual classrooms, often not properly designed by teachers emerges again. It will be necessary to investigate the different perceptions of teachers pre- and post-pandemic in future monitoring actions. Moreover, from the analysis of open questions and optional comments, the need to clarify some aspects related to the design of their teaching has emerged, freeing the field from prejudices related to the opposition between presence and distance that, unfortunately, in some cases, affect the success of the training process and educational innovation.

For the question 'Through which actions it is possible to facilitate the process of teaching innovation in your opinion?', almost $50 \%$ of the teachers indicated a positive opinion towards the creation of a community of practice at their own university, but open to the comparison with external realities. Again, 71.4\% of the professors identified the comparison 


\section{Blended learning design for teaching innovation: university teachers'perceptions}

Sannicandro, K., De Santis, A., Bellini, C., Minerva, T.

with colleagues as a lever to encourage the process of educational innovation; in this sense, the possibility of providing training moments can contribute to the exchange of good practices.

Finally, with regard to the data that emerged on the use of digital tools and resources to be integrated into one's own teaching practice, it should be remembered that the questionnaire submitted in this contribution was administered before the COVID-19 emergency, which, to some extent, 'shook up' certainties and forced the use of unprecedented solutions for all the courses and subjects in our university - and digital tools and resources on a massive scale.

It is evident that the support offered by resources, digital tools and the introduction of innovative methodologies is not sufficient to guarantee a change of course capable of fostering the 'good outcome' of the learning pathway, the development of transversal competences and the building of professionalism in students. It is necessary - in relation to the diffusion of the construct of the faculty development programme for teachers - to construct communities of practice between teachers and other professional figures involved, with the aim of encouraging the development of innovation processes and at the same time acting on the quality of teaching in the university system.

\section{Conclusions and Future Research Directions}

In relation to the complex scenario that emerged, it will be interesting - in the continuation and resumption of the monitoring actions - to verify the changes in the use of these pre- and post-pandemic solutions. What practices will be able to sediment in teachers' future planning experiences? Can we still speak of a real opposition between student-centred and teacher-centred approaches? What are the effects of the two approaches on learning processes and didactic innovation? The latest reports by EDUCAUSE and the New Media Consortium (NMC) Horizon Report - Higher Education Edition $(2018,2019)$ show a shift towards a student-centred learning approach, in which teachers are asked to make the most of active learning methodologies: 'educators are increasingly expected to employ a variety of technology-based tools, such as digital learning resources and courseware, and engage in online discussions and collaborative authoring' (Becker et al., 2018, p. 23). It is no coincidence that in the latest EDUCAUSE report (2020), particular attention is paid to the processes of elevation of instructional design, learning engineering and UX Design: 'the field of learning design continues to evolve, influenced by not only the continued growth of online course delivery but also an increase in the number of faculty who embrace student-centered learning environments, whether on-campus or online' (p. 23).

How, then, can these processes be rethought with respect to the design and implementation of blended learning models in the university context? Certainly, teacher training and instructional design are indispensable elements for rethinking not only the technology, but also the methodology of the training courses. Training actions for teachers make it possible, for example, to support the active role of students, to encourage teamwork, to encourage participation in face-to-face and distant activities, to enhance the use of different resources and sources (both in paper and digital format) and to pursue the achievement of not only disciplinary competences, but also transversal competences in line with the occupational outlets of the courses, which are offered not only in blended mode.

The teachers' answers to the questionnaire show that the teaching design and delivery practices implemented in the design of the blended courses were useful in the preparation of other courses.

The design and delivery activities of the blended/online courses allowed us to produce guidelines on blended courses and activate working groups for discussion among teachers on teaching and curricula.

It, therefore, becomes necessary to integrate methodological, didactic, organisational and technological aspects (Salomoni \& Sancassani, 2018) that are presented in Table 4.

Table 4. Methodological, didactic, administrative and technological aspects involved in the innovation processes of university didactics

1 To reduce logistical pressure on facilities and the disadvantages caused due to travelling by students

2 To improve the university's teaching offer by adapting the structure of courses to the different needs of the student population (working students, out-of-town students, students with disabilities)

3 To develop training courses for teachers on university teaching topics

4 To improve teaching effectiveness (including instructional redesign) and student performance

5 To enhance students' ability to participate in the learning process

6 To foster the building of communities of practice and learning

7 To improve the student-university relationship both from an educational point of view (relationships with teachers and peers) and from an administrative point of view (access to secretarial procedures)

8 To make more use of interaction in the classroom from a training point of view

9 To monitor the level of learning through tracking (assessment and self-assessment)

10 To initiate reflection processes on the assessment methods in university courses 
Quoting the words of Dziuban and colleagues (2018), we could say that 'Blended learning forces us to consider the characteristics of digital technology, in general, and information communication technologies (ICTs), more specifically' (p. 3). The same authors take up the reflections of Floridi (2014) pointing out that 'The world has become an infosphere (like biosphere) where we live as inforgs. What is real for us is shifting from the physical and unchangeable to those things with which we can interact' (p. 3).

\section{References}

Becker, S. A., Brown, M., Dahlstrom, E., Davis, A., DePaul, K., Diaz, V., \& Pomerantz, J. (2018). NMC Horizon Report: 2018 Higher Education Edition. EDUCAUSE: Louisville.

Bellini, C., De Santis, A., Sannicandro, K., \& Cecconi, L. (2020). Dalla formazione dei docenti alle competenze trasversali degli studenti: un progetto di faculty development presso l’Università di Modena e Reggio Emilia. In A. Lotti, \& P.A. Lampugnani (Eds.) (pp. 259-269), Faculty Development in Italia. Valorizzazione delle competenze didattiche dei docenti universitari Genova: Genova University Press.

Boelens, R., De Wever, B., \& Voet, M. (2017). Four key challenges to the design of blended learning: A systematic literature review. Educational Research Review, 22, 1-18.

Bonk, C. J. \& Graham, C., \& (2006). Handbook of blended learning: Global Perspectives, local designs. San Francisco, CA: Pfeiffer Publishing.

Borup, J., Graham, C. R., West, R. E., Archambault, L., \& Spring, K. J. (2020). Academic Communities of Engagement: an expansive lens for examining support structures in blended and online learning. Educational Technology Research and Development, 68(2), 807-832.

Cecconi L., Sannicandro K., Bellini C. (2019). La percezione degli studenti nella valutazione dei corsi universitari erogati in modalità, Italian Journal of Educational Technology, Volume 27, n.3, 207-226

Decreto Ministeriale n. 6/2019 - Autovalutazione, valutazione, accreditamento iniziale e periodico delle sedi e dei corsi di studio. Retrieved from https://www.miur.gov.it/web/guest/-/autovalutazione-valutazione-accreditamentoiniziale-e-periodico-delle-sedi-e-dei-corsi-di-studio

Dziuban, C., Graham, C. R., Moskal, P. D., Norberg, A., \& Sicilia, N. (2018). Blended learning: the new normal and emerging technologies. International journal of educational technology in Higher education, 15(1), 1-16.

EDUCAUSE (2018). Horizon Report Preview 2019, Higher Education Edition. Key Trends. Retrieved from https://library.educause.edu/-/media/files/library/2019/2/2019horizonreportpreview.pdf

EDUCAUSE (2019). 2020 EDUCAUSE Horizon Report. Teaching and Learning Edition. Retrieved from https://library. educause.edu/-/media/files/library/2020/3/2020_horizon_report_pdf.pdf?la=en\&hash=08A92C17998E8113BCB15DCA7BA1F467F303BA80

Federighi, P., Ranieri, M., \& Bandini, G. (2019). Digital scholarship tra ricerca e didattica: Studi, ricerche, esperienze. FrancoAngeli: Milano.

Ferguson, R., Coughlan, T., Egelandsdal, K., Gaved, M., Herodotou, C., Hillaire, G., Jones, D., Jowers, I., Kukulska-Hulme, A., McAndrew, P., Misiejuk, K., Ness, I. J., Rienties, B., Scanlon, E., Sharples, M., Wasson, B., Weller, M. and Whitelock, D. (2019). Innovating Pedagogy 2019: Open University Innovation Report 7. Milton Keynes: The Open University.

Ferrari, S., Rivoltella, P. C. (2006). Monitoraggio e valutazione. In Rivoltella, P. C. (Eds.) E-tutor. Profilo, metodi e strumenti (pp.131-148), Carocci, Roma.

Floridi, L. (2014). The 4th revolution: How the infosphere is reshaping human reality. Oxford: Oxford University Press.

Garavaglia, A., \& Petti, L. (2019). Innovation of settings in higher education. Education Sciences \& Society-Open Access Journal, 9(2).

Gikandi, J. W., Morrow, D., \& Davis, N. E. (2011). Online formative assessment in higher education: A review of the literature. Computers \& education, 57(4), 2333-2351.

Graham, C. R. (2006). Blended learning systems: Definition, current trends, and future directions. In C. J. Bonk \& C. R. Graham (Eds.), Handbook of blended learning: Global perspectives, local designs (pp. 3-21). San Francisco, CA: Pfeiffer Publishing.

Graham, C. R., Woodfield, W., \& Harrison, J. B. (2013). A framework for institutional adoption and implementation of blended learning in higher education. The internet and higher education, 18, 4-14.

Lotti A. \& Lampugnani P. A. (2020) (Eds.). Faculty Development in Italia. Valorizzazione delle competenze didattiche dei docenti universitari. Genova: Genova University Press.

Owston, R., \& York, D. N. (2018). The nagging question when designing blended courses: Does the proportion of time devoted to online activities matter? The Internet and Higher Education, 36, 22-32. 
Perla, L. \& Vinci, V. (2020). Follow up del progetto PRODID per lo sviluppo professionale dei docenti universitari: prima analisi dei Syllabi di insegnamento. In A. Lotti A. \& P. A. Lampugnani P. A. (Eds.) (pp. 111-131). Faculty Development in Italia. Valorizzazione delle competenze didattiche dei docenti universitari. Genova: Genova University Press.

Rogers, E. M. (2003). Diffusion of innovations (5th ed.). Free Press: New York, NY.

Salomoni, P., \& Sancassani, S. (2018). Ecosistemi digitali come driver di innovazione didattica. I Magnifici Incontri CRUI 2018 - Piano Nazionale Università Digitale. Retrieved from https:/www2.crui.it/crui/magnifici_incontri_crui_2018/ ATTI_I_MAGNIFICI_INCONTRI_CRUI2018.pdf

Sannicandro, K., De Santis, A., Fazlagic, B., Bellini, C., Tedeschi, C., \& Minerva, T. (2018). Attivazione, erogazione e monitoraggio dei corsi di laurea blended dell'Università degli studi di Modena e Reggio Emilia. In A. Volungeviciene, \& A. Szücs (Eds.) Exploring the Micro, Meso e Macro. Navigating between dimensions in the digital learning landscape. EDEN 2018 Annual Conference, Genoa, Italy 17-20 June 2018 (pp. 834-42). Budapest: European Distance and E-Learning Network.

Sannicandro, K., Bellini, C., De Santis, A. \& Minerva, T. (in press). La formazione dell'Instructional Designer. Atti del Convegno Faculty Development 2020 - Genova.

Spring, K. J., \& Graham, C. R. (2017). Thematic patterns in international blended learning literature, research, practices, and terminology. Online Learning, 21(4), 337- 361.

Triacca, S., Bodega, D., \& Rivoltella, P. C. (2019). Blended solution and Higher Education. The case of the Catholic University: e-tutoring for personalization. Education Sciences \& Society-Open Access, 9(2).

Varisco, B.M. (2002). Costruttivismo socio-culturale. Roma: Carocci, 2002. 